\title{
Are high flow arteriovenous accesses associated with worse
} haemodialysis?

\author{
Acessos arteriovenosos de alto débito estão associados a pior \\ hemodiálise?
}

\section{Authors \\ Ivo Laranjinha ${ }^{1}$ \\ Patrícia Matias $\mathbf{s}^{1,2,3}$ \\ Ana Azevedo ${ }^{1}$ \\ David Navarro 3 \\ Carina Ferreira ${ }^{4}$ \\ Tiago Amaral ${ }^{1}$ \\ Marco Mendes ${ }^{1,3}$ \\ Inês Aires ${ }^{1,2,3}$ \\ Cristina Jorge ${ }^{1,3}$ \\ Célia Gil ${ }^{1,3}$ \\ Anibal Ferreira ${ }^{1,2,3}$ \\ ${ }^{1}$ Dialverca - Clínica de diálise, \\ Forte da Casa, Portugal. \\ ${ }^{2}$ Faculdade de Ciências Médicas, Lisbon, Portugal. \\ ${ }^{3}$ Nephrocare - Clínica de diálise, Vila Franca de Xira, Portugal. \\ ${ }^{4}$ Universidade Nova de Lisboa, Faculdade de Ciências Médicas, Lisboa, Portugal.}

Submitted on: $07 / 25 / 2017$

Approved on: 09/13/2017.

\section{Correspondence to:}

Ivo Laranjinha.

E-mail: ivolaranjinha@gmail.com

DOI: 10.1590/2175-8239-JBN-3875

\section{Abstract}

Introduction: An arteriovenous (AV) access flow $(\mathrm{Qa})$ of $400 \mathrm{~mL} / \mathrm{min}$ is usually sufficient for an effective hemodialysis (HD), but some accesses continue developing and become high flow accesses (HFA). Some authors postulated that an HFA might shift a significant portion of dialyzed blood from the cardiac output, which could decrease HD efficiency and lead to volume overload. Objective: The aim of our study was to evaluate if HFA is associated with reduced HD efficiency and/or volume overload in prevalent HD patients. Methods: We performed a 1-year retrospective study and assessed HD efficiency by the percentage of sessions in which the $\mathrm{Kt} / \mathrm{V}>1.4$ and volume overload by bioimpedance spectroscopy. Results: The study included 304 prevalent HD patients with a mean age of 67.5 years; $62.5 \%$ were males, $36.2 \%$ were diabetics, with a median HD vintage of 48 months. Sixteen percent of the patients had a HFA (defined as $\mathrm{Qa}>2 \mathrm{~L} / \mathrm{min}$ ). In multivariate analysis, patients with HFA presented higher risk of volume overload $(\mathrm{OR}=2.67,95 \% \mathrm{CI}=1.06$ 6.71 ) and severe volume overload (OR $=4.06,95 \% \mathrm{CI}=1.01-16.39)$ and attained dry weight less frequently $(\mathrm{OR}=0.37,95 \% \mathrm{CI}=0.14-0.94)$. However, HFA was not associated with lower $\mathrm{Kt} / \mathrm{V}$. Conclusion: Our results suggest that patients with HFA have higher risk of volume overload. However, contrarily to what has been postulated, HFA was not associated with less efficient dialysis, measured by $\mathrm{Kt} / \mathrm{V}$. Randomized controlled trials are needed to clarify these questions.

Keywords: Arteriovenous Fistula; Blood Flow Velocity; Efficiency.

\section{Resumo}

Introdução: Um débito de sangue de acesso arteriovenoso (AV) (Qa) de $400 \mathrm{~mL} / \mathrm{min}$ é geralmente suficiente para uma hemodiálise (HD) eficaz, mas alguns acessos continuam se desenvolvendo e se tornam acessos de alto débito (AAD). Alguns autores postularam que um AAD poderia desviar uma porção significativa do sangue dialisado do débito cardíaco, o que poderia diminuir a eficiência da HD e levar à sobrecarga de volume. Objetivo: O objetivo do nosso estudo foi avaliar se o AAD está associado à redução da eficiência da HD e/ou à sobrecarga de volume em pacientes prevalentes em HD. Métodos: Foi realizado um estudo retrospectivo de 1 ano, e avaliada a eficiência da HD pela porcentagem de sessões em que o $\mathrm{Kt} / \mathrm{V}>1,4$ e a sobrecarga de volume avaliada pela bioimpedância. Resultados: O estudo incluiu 304 pacientes prevalentes em HD, com média de idade de 67,5 anos; $62,5 \%$ eram do sexo masculino; $36,2 \%$ eram diabéticos, com uma mediana de tempo em HD de 48 meses. Dezesseis por cento dos pacientes apresentavam AAD (definida como $\mathrm{Qa}>2 \mathrm{~L} / \mathrm{min}$ ). $\mathrm{Na}$ análise multivariada, os pacientes com AAD apresentaram maior risco de sobrecarga de volume $(\mathrm{OR}=2,67 ; \mathrm{IC} 95 \%=1,06-6,71)$ e sobrecarga severa de volume $(\mathrm{OR}=4,06$; IC95\% = 1,01-16,39) e atingiram o peso seco com menor frequência $(\mathrm{OR}=0,37$, IC $95 \%=0,14-0,94)$. No entanto, o AAD não foi associado uma menor razão Kt/V. Conclusão: Nossos resultados sugerem que pacientes com $\mathrm{AAD}$ apresentam maior risco de sobrecarga de volume. No entanto, ao contrário do que foi postulado, o AAD não foi associado à diálise menos eficiente, medida pelo Kt/V. Ensaios clínicos randomizados são necessários para esclarecer essas questões.

Palavras-chave: Fístula Arteriovenosa; Débito de Sangue do Acesso; Eficiência. 


\section{INTRODUCTION}

Adequate hemodialysis (HD) requires a functional vascular access that is able to deliver a flow rate of at least $350-400 \mathrm{~mL} / \mathrm{min}$ with minimal recirculation for the total duration of treatment. ${ }^{1,2}$ The monitoring of the access flow $(\mathrm{Qa})$ is very important for the early detection of access dysfunction ${ }^{3}$ such as high flow access (HFA). Although a higher blood flow allows easy needling and excellent blood flow rate to the dialyzer $(\mathrm{Qb})$, it has been related to some systemic deleterious consequences. ${ }^{4}$

There is no exact definition of the Qa level above which a HFA should be considered and no consensual guideline about the ideal or normal access blood flow. The guidelines from the Vascular Access Society defined an arteriovenous fistula (AVF) as a high flow fistula with a $\mathrm{Qa}$ between 1-1.5 L/min and a measured cardiopulmonary recirculation (CPR) $[\mathrm{Q} a /$ cardiac output (CO)] greater than $20 \% .^{5}$ In the absence of an exact description of a HFA, a Qa $>2 \mathrm{~L} / \mathrm{min}$ is pragmatically used as a cut-off point, since it increases the risk of cardiac failure in $\mathrm{HD}$ patients with a $\mathrm{Qa} / \mathrm{CO}$ $>20-30 \% .^{6-8}$

Considering the structural and functional cardiac adaptations associated with an AV access construction, and especially the higher risk for heart failure in patients with HFA, some patients become pre-load dependent, which causes intra-dialytic hypotension with lower ultrafiltration. ${ }^{6,7}$ Furthermore, the construction of an AV access leads to the creation of a left to right extracardiac shunt, which causes CPR, i.e., dialyzed blood from the AV access is directed to the right ventricle and pulmonary circulation, is then pumped into the systemic circulation and a portion of this dialyzed blood re-enters the access. The reentrance of the dialyzed and systemic blood mix into the access could lead to poor solute clearance. ${ }^{1,7,9}$ This mix decreases the solute concentration between blood and dialysate, which reduces the solute removal from the blood. Schneditz et al. were the first to show the association between CPR and HD efficiency with a theoretical model. ${ }^{9,10}$

Maintaining a HFA could cause functional and structural cardiac changes (cardiac toxicity) which could in the end reduce the CO. Considering the heart has a limited capacity to increase the $\mathrm{CO}$, accesses with a higher flow deviate a higher proportion of the CO, i.e. they have a greater CPR. That way, if the same access (with the same $\mathrm{Qa}$ - numerator) is maintained and the $\mathrm{CO}$ is reduced (as a consequence of the cardiac toxicity of these accesses - denominator), it means that the ratio $\mathrm{Qa} / \mathrm{CO}$ (percentage of blood deviated from the $\mathrm{CO}$ to the access) is high, which means a higher CPR..$^{9-11}$

Considering these unresolved questions, we performed a study to evaluate if a higher Qa was associated with reduced HD efficiency and/or volume overload in prevalent HD patients. We hypothesized that patients with HFA have a lower tolerability to ultrafiltration, have more volume overload, and could present a high CPR, reducing HD efficiency.

\section{SUBJECTS AND METHOdS}

\section{StUdY DESIGN}

This was an observational, 1-year retrospective, single-center study of a cohort of adult prevalent HD patients. The studied population was divided in two groups (HFA and non-HFA) according to the mean value of the last three Qa measurements, separated by at least one month. We defined a HFA as a Qa higher than $2 \mathrm{~L} / \mathrm{min}$.

All patients were dialyzed with high flux helixone filters (Fresenius ${ }^{\circledR}$ ), ultrapure water dialysate (evaluated monthly by kinetic chromogenic test) and online post-dilution hemodiafiltration. We used the dialysis FX CorDiax600 (Fresenius Medical Care), which has an effective surface of $1.6 \mathrm{~m}^{2}$ and Intrinsic Clearance for Urea (KoA) of 1.148. All patients included in the study were prescribed 4-hour HD sessions. The median HD vintage was 48 months (IQ range 24-96).

\section{Clinical CHARACTERISTICS}

Patient's data on age, gender, baseline comorbidity (diabetes, hypertension, coronary artery disease, peripheral vascular disease, and cerebrovascular disease), access type, location, and date of angiographic and surgical interventions were all extracted from the clinical database Euclid ${ }^{\circledR}$.

Biochemical parameters such as hemoglobin and albumin (reference value $>4.0 \mathrm{~g} / \mathrm{dL}$ ) were evaluated monthly and mean values were determined. Each patient underwent an echocardiographic examination during the study period ( $\mathrm{M}$ mode and 2-D) and left ventricular mass index (LVMI) was calculated by the Devereux formula. ${ }^{12}$

Patients with NYHA class greater than II were excluded from the study. 


\section{ACCESS BLOOD FLOW (OA) MEASUREMENT}

Access flow was routinely measured by thermodilution, using the Fresenius Medical Care Blood Temperature Monitor (BTM) at a Qb of $300 \mathrm{~mL} / \mathrm{min}$ using a twister device. This measurement is always started in the first hour of treatment. In grafts, the Qa was assessed monthly and in fistulas it was assessed depending on the measurement itself: if the last measure was lower than $600 \mathrm{~mL} / \mathrm{min}$, the Qa was measured monthly, if it was between 600 and $1000 \mathrm{~mL} /$ min, the evaluation was postponed to 4 months, and if the last Qa was higher than $1000 \mathrm{~mL} / \mathrm{min}$, the next evaluation was postponed to 1 year.

\section{VolUME STATUS ASSESSMENT}

Patient's volume status was evaluated monthly by bioimpedance spectroscopy using the Fresenius Medical Care Body Composition Monitor (BCM).$^{13}$ Both the absolute and relative fluid overload were assessed. According to BCM validation studies, the volume status was classified in three categories:

- Dry weight (absolute fluid overload below $1 \mathrm{~L}$ )

- Volume overloaded (absolute fluid overload above $1.1 \mathrm{~L}$ )

- Severe volume overloaded (absolute fluid overload above $2.5 \mathrm{~L}$ )

\section{DELIVERED DIALYSIS DOSE}

$\mathrm{Kt} / \mathrm{V}$ was measured using the Fresenius Medical Care Online Clearance Monitor (OCM) in all HD sessions during 1 year (approximately 139 sessions per patient). For each patient, we calculated the percentage of sessions in which the Kt/V goal $(\mathrm{Kt} / \mathrm{V}>1.4)$ was achieved.

\section{STATISTICAL ANALYSIS}

Variables were reported as frequencies for categorical variables, mean values with SD for continuous variables with normal distribution, and median values with interquartile ranges for continuous variables non-normally distributed. We applied Shapiro-Wilk test to evaluate the normality of our data. Comparison between groups (HFA and non-HFA) was performed using $T$-Test for normally distributed variables, Wilcoxon test for non-normally distributed variables and $x^{2}$ test for categorical variables.

For the purpose of the analysis, HFA was used as predictor and volume overload, mean value of $\mathrm{Kt} / \mathrm{V}$ throughout the year, and \% of $\mathrm{Kt} / \mathrm{V}>1.4$ as outcome variables.
The relationship between HFA and volume overload was studied using univariate and multivariate logistic regression models to adjust for potential confounders. The multivariable analysis was adjusted for age (statistically different in the univariable analysis), HD vintage, serum albumin, and LVMI.

The relationship between HFA and $\mathrm{Kt} / \mathrm{V}$ was studied using the Spearman correlation in a univariate analysis. Multivariate analysis was performed using a linear regression model. These models were adjusted for age (statistically different in the univariate analysis) and for dry weight, pump speed, and time of HD per session (important determinants of HD efficacy).

Statistical analysis was performed with SPSS system 21.0. For all comparisons, a $p<0.05$ was considered statistically significant.

\section{Results}

\section{Population}

The study included 304 patients, 190 (62.5\%) males, with a mean age of $67.5 \pm 14.8$ years old. A total of $110(36.2 \%)$ patients were diabetic, $219(72.0 \%)$ had hypertension, $90(29.6 \%)$ had coronary artery disease, $70(23 \%)$ peripheral arterial disease and 63 $(20.7 \%)$ had cerebrovascular disease (Table 1$)$.

\begin{tabular}{|c|c|c|}
\hline TABLE 1 & \multicolumn{2}{|c|}{$\begin{array}{l}\text { HEMODIALYSIS PARAMETERS OF THE STUDIED } \\
\text { POPULATION }\end{array}$} \\
\hline Variable & & Patients ( $n=304$ ) \\
\hline Age, yea & & $67.5 \pm 14.8$ \\
\hline Gender, & & $190(62.5)$ \\
\hline Race, C & sian & $288(94.7)$ \\
\hline HD vinte & months & $48(24-96)$ \\
\hline HD sess & duration, minutes & $245(245-247)$ \\
\hline Blood pi & speed (Ob), mL/min & $442.7 \pm 17.9$ \\
\hline Diabete & & $110(36.2)$ \\
\hline Hyperte & & $219(72.0)$ \\
\hline \multicolumn{3}{|c|}{ Access type } \\
\hline Fistula & & $225(74.0)$ \\
\hline Graft & & $79(26.0)$ \\
\hline Access & tion, proximal & $193(63.5)$ \\
\hline Access & $\mathrm{Qa} \geq 2 \mathrm{~L} / \mathrm{min}$ & 48 (15.8) \\
\hline Mean K & & $1.98 \pm 0.39$ \\
\hline Dry wei & $(\mathrm{OH}<1 \mathrm{~L})$ & 269 (88.5) \\
\hline Volume & rload $(\mathrm{OH}>1 \mathrm{~L})$ & $35(11.5)$ \\
\hline Severe v & ne overload $(\mathrm{OH}>2.5 \mathrm{~L})$ & $10(3.3)$ \\
\hline
\end{tabular}


All patients had a functioning AV access for HD: approximately three quarters $(\mathrm{n}=225 ; 74.0 \%)$ had a fistula and one quarter $(\mathrm{n}=79,26 \%)$ had a graft. In our population, $15.8 \%$ of the patients had a HFA, i.e. an access with $\mathrm{Qa}>2 \mathrm{~L} / \mathrm{min}$. The mean $\mathrm{Kt} / \mathrm{V}$ value was 1.98 and $88.5 \%$ of the patients achieved their dry weight.

Patients with a HFA were younger (62.1 vs. 68.5 years, $p=0.015)$, were under HD for longer time $(60$ vs. 48 months, $p=0.034$ ) and had a lower prevalence of diabetes (14.6vs. $40.2 \%, p<0.001)$. There was no significant difference in gender distribution and prevalence of coronary artery disease, cerebrovascular disease, and peripheral artery disease between groups (Table 2).

In respect to access characteristics, we found that $\mathrm{Qa} \geq 2 \mathrm{~L} / \mathrm{min}$ was more frequent in fistulas comparatively to grafts $(91.7 v s .8 .3 \%, p=0.001)$ and in proximal accesses than in distal $(75 v s .25 \%, p=$ $0.043)$.
Patients with a HFA had higher left ventricular mass index (146.2 vs. $\left.130.2 \mathrm{~g} / \mathrm{m}^{2}, p=0.035\right)$ and lower pulse pressure (71.7 vs. $78.0 \mathrm{mmHg}, p=0.037)$. Although not statistically significant, patients with a HFA presented a higher proportion of hypertension (77.1 vs. $71.1 \%$ ) and lower LVEF (55.1 vs. 60.7\%).

\section{- Volume overload}

Eighty-nine percent of the patients achieved the dry weight and $11.5 \%$ had volume overloaded $(\mathrm{OH}$ $>1 \mathrm{~L}$ ).

In univariate analysis, we found that patients with a HFA had severe volume overloaded more frequently (2.3 vs. $8.3 \%$, OR 3.79, 95\%CI $=1.03-13.97)$. However, the distribution of patients for dry weight and volume overload categories was not different between groups.

A logistic regression analysis was performed to verify the effect of having a HFA on the chance of

TABLE 2 CLINICAL AND LABORATORY CHARACTERISTICS OF PATIENTS WITH HFA AND NON-HFA

\begin{tabular}{|c|c|c|c|}
\hline & $\mathrm{Qa}<2 \mathrm{~L} / \min (\mathrm{n}=256)$ & $\mathrm{Q} a \geq 2 \mathrm{~L} / \min (\mathrm{n}=48)$ & $p$ \\
\hline Age, years & $68.5 \pm 14.1$ & $62.1 \pm 17.5$ & 0.015 \\
\hline Gender, male & $155(60.5)$ & 35 (72.9) & ns \\
\hline Race, Caucasian & $245(95.7)$ & $43(89.6)$ & ns \\
\hline HD vintage, months & $48(24-84)$ & $60(27-108)$ & 0.034 \\
\hline HD sessions duration, minutes & $245(245-247)$ & $246(245-247)$ & ns \\
\hline Blood pump speed (Qb), mL/min & $442.7 \pm 18.0$ & $443.3 \pm 17.8$ & ns \\
\hline Dry weight (kg) & $69.9 \pm 13.5$ & $70.7 \pm 11.3$ & ns \\
\hline Diabetes & $103(40.2)$ & $7(14.6)$ & $<0.001$ \\
\hline Hemoglobin (g/dL) & $11.1 \pm 1.1$ & $11.2 \pm 1.1$ & ns \\
\hline Serum Albumin (g/dL) & $4.0 \pm 0.3$ & $4.1 \pm 0.3$ & ns \\
\hline \multicolumn{4}{|l|}{ Access type } \\
\hline Fistula & $181(70.7)$ & $44(91.7)$ & 0.001 \\
\hline Graft & $75(29.3)$ & $4(8.3)$ & \\
\hline Access location, proximal & $157(61.3)$ & $36(75.0)$ & 0.043 \\
\hline Pulse pressure, $\mathrm{mmHg}$ & $78.0 \pm 15.9$ & $71.7 \pm 17.6$ & 0.037 \\
\hline Mean Blood Pressure, mmHg & $92.0 \pm 13.2$ & $90.0 \pm 14.5$ & ns \\
\hline Heart Rate, bpm & $71.7 \pm 10.6$ & $72.1 \pm 10.0$ & ns \\
\hline Left Ventricular Mass Index $\left(\mathrm{g} / \mathrm{m}^{2}\right)$ & $130.2 \pm 30.9$ & $146.2 \pm 47.3$ & 0.035 \\
\hline Left Ventricular Ejection Fraction (\%) & $60.7 \pm 13.6$ & $55.1 \pm 17.8$ & ns \\
\hline Pulmonary Artery Pressure (mmHg) & $39.2 \pm 12.9$ & $34.1 \pm 13.3$ & ns \\
\hline Hypertension & $182(71.1)$ & $37(77.1)$ & ns \\
\hline Coronary Artery Disease & $80(31.3)$ & $10(20.8)$ & ns \\
\hline Peripheral artery disease & $63(24.6)$ & $7(14.6)$ & ns \\
\hline Cerebrovascular disease & $56(21.9)$ & $7(14.6)$ & ns \\
\hline
\end{tabular}

* Values reported as mean $\pm \mathrm{SD}$, median (interquartile range) or frequencies [n (\%)]. 
having volume overload adjusting for age (years), HD vintage (months), serum albumin $(\mathrm{g} / \mathrm{dL})$, and LVMI $\left(\mathrm{g} / \mathrm{m}^{2}\right)$. We found that an access with $\mathrm{Qa}>2 \mathrm{~L} / \mathrm{min}$ was significantly associated with the risk of volume overload $(\mathrm{OR}=2.67,95 \% \mathrm{CI}=1.06-6.71)$ and severe volume overload $(\mathrm{OR}=4.06,95 \% \mathrm{CI}=1.01-16.39)$. In the same analysis we also found that patients with HFA attained the dry weight less frequently $(\mathrm{OR}=$ $0.37,95 \% \mathrm{CI}=0.14-0.94)$.

\section{- $\mathrm{Kt} / \mathrm{V}$}

The mean $\mathrm{Kt} / \mathrm{V}$ of our population was 1.98 and the Kt/V goal was attained in $97 \%$ of the sessions. Patients with a HFA did not have a different mean $\mathrm{Kt} / \mathrm{V}$ value or a different proportion of sessions in which the Kt/V was attained comparing with patients with an AV access of $\mathrm{Qa} \leq 2 \mathrm{~L} / \mathrm{min}$.

We performed a multiple regression analysis to investigate whether the $\mathrm{Kt} / \mathrm{V}$ value could be predicted based on $\mathrm{Qa}>2 \mathrm{~L} / \mathrm{min}$, in a model adjusted to age (years), dry weight $(\mathrm{Kg})$, blood pump speed $(\mathrm{mL} / \mathrm{min})$ and time of each HD session (minutes). This model was not significant (Table 3).
We also compared the patients with $\mathrm{Qa}<1 \mathrm{~L} / \mathrm{min}$ with patients with $\mathrm{Qa}>1 \mathrm{~L} / \mathrm{min}$ and the results were not different from those described above.

\section{Discussion}

We believe this is the first study that investigated the relationship between HFA, volume overload, and HD efficiency. We found that having a HFA, at least when the Qa was greater than $2 \mathrm{~L} / \mathrm{min}$, was associated with a higher risk of volume overload, but not to dialysis efficiency, evaluated by $\mathrm{Kt} / \mathrm{V}$.

There are many studies about the immediate and late cardiac and neurohormonal adaptations after the creation of an AV access. These modifications lead to a compensatory increase in $\mathrm{CO}$, heart rate, cardiac contractility, and blood volume. ${ }^{10,14}$ Some studies about the cardiac hemodynamic effects of AV accesses suggest that patients with a HFA have elevated CO, higher cardiac index, less subendocardial perfusion, and increased left ventricular cavity size..$^{5,14-16}$ These patients could also present more cardiac diastolic dysfunction and higher ANP/BNP levels. ${ }^{10}$

Several cases of high-output cardiac failure in patients with a HFA have been reported, ${ }^{17-19}$ especially

\begin{tabular}{|c|c|c|c|c|c|c|}
\hline \multirow{3}{*}{\multicolumn{2}{|c|}{$\begin{array}{l}\text { EFFICIENCY AND VOLL } \\
\text { MULTIVARIATE ANALYS }\end{array}$}} & \multirow{2}{*}{\multicolumn{2}{|c|}{ Univariate analysis }} & \multirow[b]{3}{*}{ OR $(95 \% \mathrm{Cl})$} & \multirow[t]{3}{*}{ FA (UNIV } & \multirow{3}{*}{$\begin{array}{l}\text { ATE AND } \\
\begin{array}{c}\text { Multivariate } \\
\text { analysis }\end{array} \\
\text { OR }(95 \% \mathrm{CI})\end{array}$} \\
\hline & & & & & & \\
\hline & & $\begin{array}{l}\mathrm{Oa}<2 \mathrm{~L} / \mathrm{min} \\
(\mathrm{n}=256)\end{array}$ & $\begin{array}{l}\mathrm{Q} a \geq 2 \mathrm{~L} / \mathrm{min} \\
\quad(\mathrm{n}=48)\end{array}$ & & & \\
\hline \multicolumn{2}{|c|}{ Dry weight $(\mathrm{OH} \leq 1 \mathrm{~L})$} & $230(89.8)$ & 39 (81.3) & $\begin{array}{c}0.49 \\
(0.21-1.12)\end{array}$ & ns & $\begin{array}{c}0.37 \\
(0.14-0.94)\end{array}$ \\
\hline \multicolumn{2}{|c|}{ volume overload $(\mathrm{OH}>1 \mathrm{~L})$} & $26(10.2)$ & $9(18.8)$ & $\begin{array}{c}2.04 \\
(0.89-4.68)\end{array}$ & ns & $\begin{array}{c}2.67 \\
(1.06-6.71)\end{array}$ \\
\hline \multicolumn{2}{|c|}{$\begin{array}{l}\text { Severe volume overload }(\mathrm{OH}> \\
2.5 \mathrm{~L})\end{array}$} & $6(2.3)$ & $4(8.3)$ & $\begin{array}{c}3.79 \\
(1.03-13.97)\end{array}$ & 0.056 & $\begin{array}{c}4.06 \\
(1.01-16.39)\end{array}$ \\
\hline \multicolumn{2}{|c|}{$\% \mathrm{VO}>15 \%$} & $52(22.0)$ & $9(21.4)$ & $\begin{array}{c}0.965 \\
(0.43-2.15)\end{array}$ & ns & $\begin{array}{c}0.79 \\
(0.33-1.93)\end{array}$ \\
\hline \multicolumn{2}{|c|}{$\%$ VO > $20 \%$} & $12(5.1)$ & $3(7.1)$ & $\begin{array}{c}1.44 \\
(0.39-5.32)\end{array}$ & ns & $\begin{array}{c}1.65 \\
(0.39-6.99)\end{array}$ \\
\hline \multicolumn{2}{|l|}{$\mathrm{Kt} / \mathrm{N}$} & $1.99 \pm 0.40$ & $1.93 \pm 0.35$ & $\begin{array}{c}0.52 \\
(0.07-1.18)\end{array}$ & ns & $\begin{array}{c}0.03 \\
(0.00-3.09)\end{array}$ \\
\hline \multicolumn{2}{|c|}{$\begin{array}{l}\% \text { of sessions that } \mathrm{Kt} / \mathrm{N} \text { was } \\
\text { attained in } 1 \text { year }\end{array}$} & 97.2 & 95.3 & $\begin{array}{c}1.69 \\
(0.34-8.40)\end{array}$ & ns & $\begin{array}{c}1.33 \\
(0.20-8.71)\end{array}$ \\
\hline
\end{tabular}

* Values expressed as mean $\pm \mathrm{SD}$, median or frequencies [n (\%)]. Relative pre-dialytic volume overload (\% VO) was calculated as: \% VO = VO [L]/ extracellular water $[\mathrm{L}]^{*} 100$ at baseline.

${ }^{5}$ Multivariate analysis: logistic regression for binary outcomes and linear regression for continuous outcomes. The models were adjusted for age (years), dry weight $(\mathrm{kg})$, pump speed $(\mathrm{mL} / \mathrm{min})$, and HD sessions length (minutes) to study the HD efficiency $(\mathrm{Kt} / \mathrm{N})$ and for age, HD vintage, serum albumin $(\mathrm{g} / \mathrm{dL})$ and LVMI to study the volume status. 
in transplanted patients. $\mathrm{A} \mathrm{Q} a / \mathrm{CO}$ ratio higher than 0.3 is considered a risk factor for high-output cardiac failure, however this cut-off has not yet been validated in prospective trials. ${ }^{20}$ Other studies showed echocardiographic and clinical improvement following AV access closure or flow reduction. ${ }^{21-25}$ An established relationship between $\mathrm{Qa}$ and $\mathrm{CO}$ was described by Basile et.al. ${ }^{6}$ in a $3^{\text {rd }}$ order polynominal regression model, in which the CO did not vary significantly for Qa between 0.95 and $2.2 \mathrm{~L} / \mathrm{min}$. These authors also show that a $\mathrm{Qa}>2 \mathrm{~L} / \mathrm{min}$ was a strong predictor of high-output heart failure. ${ }^{6}$

Prospective studies found indirect signs (e.g. increased serum ANP) that the creation of an AV access develops a state of volume overload, at least immediately after the creation, ${ }^{10,26}$ which have been demonstrated in traumatic fistulas. Besides the increase in blood volume, it was also demonstrated that in traumatic fistulas the greater the fistula blood flow the greater the increase in blood volume. ${ }^{27}$

In our cohort study, patients with a HFA presented higher LVMI, and although not statistically significant, these patients also had a higher proportion of hypertension and lower LVEF.

The cardiac adaptations in patients with a HFA could be associated with a lower tolerability to ultrafiltration and interfere with the achievement of dry weight, which could have prognostic consequences. ${ }^{7}$ In this study, we hypothesized that a higher $\mathrm{Qa}$ is associated with a higher risk of volume overload and our findings support this hypothesis. The odds ratio of volume overload and severe volume overload were 2.67 and 4.06 times higher for patients with a HFA than for patients with $\mathrm{Qa}<2 \mathrm{~L} / \mathrm{min}$. We also found that the patients with a HFA attained dry weight less frequently, with an odds ratio 0.37 times lower compared to patients with $\mathrm{Qa}<2 \mathrm{~L} / \mathrm{min}$.

The making of an $\mathrm{AV}$ access leads to a left to right extra-cardiac shunt causing CPR, and a significant proportion of dialyzed blood re-enters the access, which could theoretically lead to poor solute clearance. Thus, accesses with higher blood flow drive a higher percentage of $\mathrm{CO}$ to the access, i.e., have greater CPR. Some authors postulated that a persistent HFA could be associated with under-dialysis. ${ }^{8}$ These authors reinforce the important potential for cardiac toxicity, but also the potential systemic consequences of a HFA, such as the "global steal syndrome", under-dialysis, and wasting. ${ }^{7,27}$
Contrarily to what has been postulated, the higher CPR related with a HFA is not associated with lower HD efficiency. We should note that HD adequacy has multiple components, such as nutrition, anemia management, and mineral and bone disorders. Therefore, this issue needs to be clarified in prospective randomized studies, where other components of HD efficiency are considered, besides the Kt/V.

Although a previous study did not find an increased risk of all-cause mortality associated with higher $\mathrm{Qa},{ }^{28}$ studies are needed to investigate if, when, and which patients would benefit from the reduction of Qa in HFA. ${ }^{29}$

Our results corroborate the new "patient first" paradigm currently accepted in the field of vascular accesses for hemodialysis in opposition to the old "fistula first" paradigm. This change was based on data suggesting that the presence of an AVF can contribute to the high CV morbidity in HD patients, called by Richard Amerling "arteriovenous fistula toxicity". ${ }^{7}$ With this new paradigm, experts want to alert that AVF is not the best choice for all patients. The best vascular access for each patient must be defined individually, based on the risk of heart failure and/or ischemic steal syndrome, CV comorbidities, patient desires, life expectancy, etc. ${ }^{7,8}$

A limitation of our study is its retrospective nature and an HD population from a single center, which could interfere in the generalization of our results. Another important limitation is that $\mathrm{CO}$, which is a very important determinant of $\mathrm{Q} a$, was not evaluated in our study, as echocardiography routine performed in our center does not include doppler study.

In conclusion, our results suggest that a HFA is associated with higher risk of volume overload and lower capacity of reach dry weight. Contrarily to what has been postulated, patients with a HFA do not have less efficient $\mathrm{HD}$, measured by Kt/V. Randomized controlled trials are needed to examine whether higher Qa adds difficulty in reaching dry weight, if it is cardiovascular risk factor, and if it is associated with under dialysis.

\section{References}

1. Sidawy AN, Gray R, Besarab A, Henry M, Ascher E, Silva M $\mathrm{Jr}$, et al. Recommended standards for reports dealing with arteriovenous hemodialysis accesses. J Vasc Surg 2002;35:603-10.

2. McCarley P, Wingard RL, Shyr Y, Pettus W, Hakim RM, Ikizler TA. Vascular access blood flow monitoring reduces access morbidity and costs. Kidney Int 2001;60:1164-72.

3. Wijnen E, Planken N, Keuter X, Kooman JP, Tordoir JH, de Haan MW, et al. Impact of a quality improvement programme based on vascular access flow monitoring on costs, access occlusion and access failure. Nephrol Dial Transplant 2006;21:3514-9. 
4. Agarwal AK. Systemic Effects of Hemodialysis Access. Adv Chronic Kidney Dis 2015;22:459-65.

5. Wijnen E, Keuter XH, Planken NR, van der Sande FM, Tordoir $\mathrm{JH}$, Leunissen $\mathrm{KM}$, et al. The relation between vascular access flow and different types of vascular access with systemic hemodynamics in hemodialysis patients. Artif Organs 2005;29:9604.

6. Basile C, Lomonte C, Vernaglione L, Casucci F, Antonelli M, Losurdo N. The relationship between the flow of arteriovenous fistula and cardiac output in haemodialysis patients. Nephrol Dial Transplant 2008;23:282-7.

7. Amerling R, Ronco C, Kuhlman M, Winchester JF. Arteriovenous fistula toxicity. Blood Purif 2011;31:113-20.

8. Basile C, Lomonte C. Pro: the arteriovenous fistula is a blessing of God. Nephrol Dial Transplant 2012;27:3752-6.

9. Schneditz D, Kaufman AM, Polaschegg HD, Levin NW, Daugirdas JT. Cardiopulmonary recirculation during hemodialysis. Kidney Int 1992;42:1450-6.

10. Iwashima $Y$, Horio $T$, Takami $Y$, Inenaga T, Nishikimi T, Takishita S, et al. Effects of the creation of arteriovenous fistula for hemodialysis on cardiac function and natriuretic peptide levels in CRF. Am J Kidney Dis 2002;40:974-82.

11. Miller GA, Hwang WW. Challenges and management of high-flow arteriovenous Fistulae. Semin Nephrol 2012;32:545-50.

12. Devereux RB, Alonso DR, Lutas EM, Gottlieb GJ, Campo E, Sachs I, et al. Echocardiographic assessment of left ventricular hypertrophy: comparison to necropsy findings. Am J Cardiol 1986;57:450-8.

13. Ponce P, Pinto B. Measuring vascular access flow: the accuracy of different methods. Port J Nephrol Hypert 2011;25:151-5.

14. Savage MT, Ferro CJ, Sassano A, Tomson CR V. The impact of arteriovenous fistula formation on central hemodynamic pressures in chronic renal failure patients: a prospective study. Am J Kidney Dis 2002;40:753-9.

15. Dundon BK, Torpey K, Nelson AJ, Wong DT, Duncan RF, Meredith IT, et al. The deleterious effects of arteriovenous fistula-creation on the cardiovascular system: a longitudinal magnetic resonance imaging study. Int J Nephrol Renovasc Dis 2014;7:337-45.

16. Ori Y, Korzets A, Katz M, Erman A, Weinstein T, Malachi $\mathrm{T}$, et al. The contribution of an arteriovenous access for hemodialysis to left ventricular hypertrophy. Am J Kidney Dis 2002;40:745-52.
17. Stern AB, Klemmer PJ. High-output heart failure secondary to arteriovenous fistula. Hemodial Int 2011;15:104-7.

18. Khreiss M, Haddad FF, Musallam KM, Medawar W, Daouk M, Khalil I. High-output cardiac failure secondary to a large arteriovenous fistula: a persistent threat to the dialysis and kidney transplant patient. NDT Plus 2009;2:147-8.

19. Raza F, Alkhouli M, Rogers F, Vaidya A, Forfia P. Case series of 5 patients with end-stage renal disease with reversible dyspnea, heart failure, and pulmonary hypertension related to arteriovenous dialysis access. Pulm Circ 2015;5:398-406.

20. MacRae JM, Pandeya S, Humen DP, Krivitski N, Lindsay RM. Arteriovenous fistula-associated high-output cardiac failure: a review of mechanisms. Am J Kidney Dis 2004;e17-22.

21. Unger P, Wissing KM, de Pauw L, Neubauer J, Borne P. Reduction of left ventricular diameter and mass after surgical arteriovenous fistula closure in renal transplant recipients. Transplantation 2002;74:73-9.

22. van Duijnhoven EC, Cheriex EC, Tordoir JH, Kooman JP, van Hooff JP. Effect of closure of the arteriovenous fistula on left ventricular dimensions in renal transplant patients. Nephrol Dial Transplant 2001;16:368-72.

23. Dundon BK, Torpey DK, Nelson AJ, Wong DTL, Duncan RF, Meredith IT, et al. Beneficial cardiovascular remodeling following arterio-venous fistula ligation post-renal transplantation: a longitudinal magnetic resonance imaging study. Clin Transplant 2014;28:916-25.

24. Balamuthusamy S, Jalandhara N, Subramanian A, Mohanaselvan A. Flow reduction in high-flow arteriovenous fistulas improve cardiovascular parameters and decreases need for hospitalization. Hemodial Int 2016;20:362-8.

25. Murray BM, Rajczak S, Herman A, Leary D. Effect of surgical banding of a high-flow fistula on access flow and cardiac output: intraoperative and long-term measurements. Am J Kidney Dis 2004;44:1090-6.

26. Ori Y, Korzets A, Katz M, Perek Y, Zahavi I, Gafter U. Haemodialysis arteriovenous access--a prospective haemodynamic evaluation. Nephrol Dial Transplant 1996;11:94-7.

27. Alkhouli M, Sandhu P, Boobes K, Hatahet K, Raza F, Boobes Y. Cardiac complications of arteriovenous fistulas in patients with end-stage renal disease. Nefrologia 2015;35:234-45.

28. Al-Ghonaim M, Manns BJ, Hirsch DJ, Gao Z, Tonelli M. Relation between access blood flow and mortality in chronic hemodialysis patients. Clin J Am Soc Nephrol 2008;3:387-91.

29. Basile C, Lomonte C. When and how should an arterio-venous access be modified because of a high blood flow rate? Semin Dial 2011;24:396-8.ww 